\title{
Neurotrophins Protect Cultured Cerebellar Granule Neurons against the Early Phase of Cell Death by a Two- Component Mechanism
}

\author{
Michael J. Courtney, Karl E. O. Åkerman, and Eleanor T. Coffey \\ Department of Biochemistry and Pharmacy, Åbo Akademi University, BioCity, Turku, Finland
}

\begin{abstract}
Cerebellar granule neurons cultured with serum develop a mature neuronal phenotype, including stimulus-coupled release of glutamate, and depend on elevated potassium for survival. We find that cells cultured with serum undergo two phases of cell death. By $6 \mathrm{~d}$ in vitro, $30-50 \%$ of the cells present are dead; after this time the remaining cells die. Elevated potassium prevents only this later phase of death, whereas neurotrophins protect these cells against the early phase of death. Factors that bind $\mathrm{p} 75^{\mathrm{NTR}}$ or TNF-R, members of the same receptor family, exhibit voltage-sensitive calcium channel-dependent protection, whereas ligands of expressed Trk receptors show additional calcium channel-independent protection. The cells express TrkB protein and show elevated c-Fos and c-Jun levels
\end{abstract}

in response to BDNF. No TrkA is detected, although $p 75^{\mathrm{NTR}}$ protein is expressed and NGF induces depolarizationdependent elevation of c-Jun levels. In the presence of the protein kinase $\mathrm{C}$ inhibitor bisindolylmaleimide, BDNF-induced survival promotion is reduced partially, whereas NGF-induced death is unmasked. Basal survival mechanisms are insensitive to inhibition of $\mathrm{PK}-\mathrm{C}$ or $\mathrm{PI}-3$ kinase. We conclude that BDNF promotes survival in part via its TrkB receptor, whereas there is an additional pathway promoting survival and elevating c-Jun evoked by both NGF and BDNF via a non-Trk receptor.

Key words: NGF; BDNF; TNF; neurotrophins; p75 ${ }^{N T R}$; TrkB; cell death; cerebellar granule neurons; $P K-C$
Cultured cerebellar granule neurons, a popular model CNS culture for the study of neuronal signaling and development, express a wide range of receptor subtypes and develop stimulus-coupled glutamate release when cultured in serum-based medium. Under these culture conditions the cells depend on chronic depolarization or other calcium-elevating stimuli for continued survival (Thangnipon et al., 1983; Gallo et al., 1987; Balazs et al., 1988b,c, 1990). Without such stimuli a delayed apoptotic death occurs (Copani et al., 1995). This dependence has been proposed to mimic a trophic requirement of cells in the cerebellar granule layer for innervation by the mossy fibers (Balazs et al., 1990). During the first 3-5 weeks of postnatal life, there is a well characterized major loss of granule neurons in the cerebellum (Landis and Sidman, 1978). However, considerable cell loss occurs at postnatal day 5-6 because of an early phase of apoptosis (Wood et al., 1993; Krueger et al., 1995).

The neurotrophins NGF, BDNF, and neurotrophin-3 (NT-3) are survival-promoting factors reported to act via their specific tyrosine kinase receptors TrkA, TrkB, and TrkC, respectively (for review, see Glass and Yancopoulos, 1993), and via $\mathrm{p} 75^{\mathrm{NTR}}$, the nonselective neurotrophin receptor of the tumor necrosis factor

\footnotetext{
Received Jan. 31, 1997; revised March 17, 1997; accepted March 25, 1997.

This work was supported by the Academy of Finland, the Wellcome Trust, the Sigrid Jusélius Stiftelse, the Magnus Ehrnrooth Stiftelse, the Oskar Öflund Stiftelse, and the Finska Vetenskaps-Societeten. We thank Heiti Paves (Estonian Academy of Sciences, Tallinn, Estonia) for providing some neurotrophins for pilot experiments, Louis Reichardt (University of California, San Francisco) for providing us with TrkA-specific antiserum, and Moses Chao (Cornell University Medical College, New York) for providing us with anti-p $75^{\text {NTR }}$ antiserum 9651.

Correspondence should be addressed to Dr. Michael J. Courtney, Department of Biochemistry and Pharmacy, Åbo Akademi University, BioCity, P.O. Box 66, FIN20521 Turku, Finland.

Dr. Åkerman's present address: Department of Physiology and Medical Biophysics, Uppsala University, BMC Box 572, S-75123 Uppsala, Sweden.

Copyright (C) 1997 Society for Neuroscience $0270-6474 / 97 / 174201-11 \$ 05.00 / 0$
}

(TNF)/Fas/CD40 family (Mahadeo et al., 1994). Activation of Trks initiates a number of signaling cascades, including Rasdependent activation of the extracellular signal-regulated kinase/ microtubule-associated protein (ERK/MAP) kinase cascade (Ohmichi et al., 1992), which induces $c$-fos transcription (Karin and Hunter, 1995). The signaling events subsequent to ligand binding to $\mathrm{p} 75^{\mathrm{NTR}}$, initially characterized as altering the specificity and binding of coexpressed Trks (for review, see Chao and Hempstead, 1995), include the activation of sphingomyelinase (Dobrowsky et al., 1994), NF- $\kappa$ B (Carter et al., 1996a), and Jun kinase (JNK; Casaccia-Bonnefil et al., 1996).

BDNF has been reported to reduce the death of cerebellar granule neurons in serum-free culture as early as $2 \mathrm{~d}$ in vitro (Gao et al., 1995) (see also Segal et al., 1992; Lindholm et al., 1993). However, in the absence of serum, delayed death does not occur (Kingsbury et al., 1985). Because cerebellar granule neurons in culture require serumcontaining medium to acquire depolarization-dependent survival and a mature physiology, such as expression of amino acid carriers and stimulus-coupled neurotransmitter release (Balazs et al., 1988a), serum-based cultures may mimic more closely the cells in vivo. Thus we have investigated the requirements for survival promotion by neurotrophins under these more physiological conditions.

In this study we show that there is considerable death of cerebellar granule neurons developing in serum-based culture before depolarization-dependent survival. We find that NGF, BDNF, NT-3, and TNF all protect against basal cell death. Two components of protection by neurotrophins are resolved: (1) factors that bind $\mathrm{p} 75^{\mathrm{NTR}}$ or TNF-R, members of the same receptor family, provide protection dependent on calcium channel activity; (2) those factors that are able to bind the Trk receptors present provide an additional calcium channel-independent component of protection. In addition, basal survival mechanisms exist that allow partial survival in the absence of neurotrophins. 


\section{MATERIALS AND METHODS}

Cell culture. Cerebellar granule neurons were prepared from 7-d-old rats as previously described (Courtney and Nicholls, 1992), except that cells were plated at $250,000 / \mathrm{cm}^{2}$. Dissociated cells were plated onto either poly-L-lysine-coated coverslips $(10.5 \mathrm{~mm} \times 10.5 \mathrm{~mm})$ and cultured in 24-well plates for cell death studies or plated on poly-L-lysine-coated 6-well plates for immunoblot analysis. Cells were cultured in Minimum Essential Media (MEM; Life Technologies, Paisley, Scotland) supplemented with $10 \%(\mathrm{v} / \mathrm{v})$ fetal calf serum (Life Technologies), $33 \mathrm{~mm}$ glucose, $2 \mathrm{~mm}$ glutamine, $50 \mathrm{U} / \mathrm{ml}$ penicillin, $50 \mu \mathrm{M}$ streptomycin, and 20 $\mathrm{mM}$ supplementary $\mathrm{KCl}$, as indicated (i.e., low $\mathrm{KCl}=5.4 \mathrm{mM} \mathrm{KCl}$; elevated $\mathrm{KCl}=25.4 \mathrm{mM} \mathrm{KCl}$ ). Culture medium was replaced at $1 \mathrm{~d}$ in vitro (DIV). When experiments were performed on cells older than 6 DIV, medium also was replaced at 7 DIV. However, the depolarization dependence of survival observed also was observed in preliminary experiments without this medium change and thus cannot be attributed to this medium change. Cytosine arabinofuranoside (10 $\mu \mathrm{M}$; Sigma, St. Louis, MO) was included in the culture medium change at $1 \mathrm{~d}$ to inhibit non-neuronal cell proliferation. At this time $1 \mu \mathrm{M}$ nifedipine (Sigma), 10 $\mathrm{ng} / \mathrm{ml}$ of NGF (>98\%; Alomone, Jerusalem, Israel), BDNF (>96\%; Peprotech, Princeton, NJ), NT-3 (>98\%; Peprotech), TNF- $\alpha$ (>97\%; Peprotech), and $10 \mathrm{~nm}$ 12-O-tetradecanoyl phorbol-13-acetate (TPA; Sigma) plus the inhibitors wortmannin (100 nM; Calbiochem, La Jolla, CA), bisindolylmaleimide GF 109203X (1 $\mu \mathrm{M}$; Calbiochem), curcumin (10 $\mu \mathrm{M}$; Sigma), or $\mathrm{C}_{2}$ ceramide (Sigma) were added, as indicated.

Purity of the preparation. The preparation used in this study is a well characterized one, the purity of which has been the subject of several studies. The cultures have been reported to contain $\sim 95 \%$ small interneurons, predominantly granule neurons (Thangnipon et al., 1983), and 4-6\% GABAergic neurons (Resink et al., 1994). This is achieved in part by the huge abundance of granule neurons in the cerebellum and in part by the isolation procedure that does not allow the survival of larger, earlier differentiating neurons such as Purkinje cells (Weber and Schachner, 1984). Culturing in serum-containing medium supplemented with the antimitotic agent arabinosyl cytosine is more effective than culturing without serum at reducing the proportion of contaminating cells. Under the former conditions the major contaminants are $\mathrm{GFAP}^{+}$ astrocytes, accounting for 1-3\% of cells (Kingsbury et al., 1985). AntiGFAP staining of parallel cultures to those used in this study reveals $\mathrm{GFAP}^{+}$contamination within this range. These $\mathrm{GFAP}^{+}$cells are morphologically distinguishable, having either very large nuclei or a large number of thick processes. At the wavelengths used, propidium iodide stains protein to a minor extent, and the Hoechst stain gives the background a slight green fluorescence, allowing morphological identification of both characteristics of contaminating cells during the counting of nuclei. Thus these contaminants are excluded readily from the statistics. This leaves the possibility that some of the dead cells counted might be non-neuronal cells and that this might interfere with the measurements. However, a minor contaminant of $3 \%$ of living cells in control cultures would have to become over fourfold more prevalent in treated cultures to account for a $10 \%$ measured reduction in cell death. No such increases of these morphologically distinguishable cells were detected. Contaminating neurons from the cerebellum are also distinguishable by their large nuclei; the same argument is valid for these.

Cell death measurements. At the times indicated in the figures, Hoechst $33342 /$ propidium iodide in MEM was added to a final concentration of 5 $\mu \mathrm{g} / \mathrm{ml}$ Hoechst 33342 (Molecular Probes, Eugene, OR) and $20 \mu \mathrm{g} / \mathrm{ml}$ propidium iodide (Sigma). After $25 \mathrm{~min}$, cells were washed in PBS, fixed for $30 \mathrm{~min}$ in $4 \%$ paraformaldehyde, washed again, and mounted in Mowiol 4-88 (Hoechst AG, Frankfurt am Main, Germany) mounting medium (Harlow and Lane, 1988) containing $2.5 \%$ (w/v) 1,4diazabicyclo[2.2.2] octane (DABCO). Slides were examined with a fluorescence microscope (Leica, Heerbrugg, Switzerland) equipped with a 1000U CCD Camera (Electrim, Princeton, NJ) under control of software developed by the authors. An image at 7-amino-4-methylcoumarin-3acetic acid- $N^{\prime}$-hydroxysuccinimide ester wavelengths (excitation bandpass 340-380 nm, dichroic $400 \mathrm{~nm}$, emission long-pass $425 \mathrm{~nm}$ ) and an image at rhodamine B wavelengths (excitation bandpass $515-560 \mathrm{~nm}$, dichroic $580 \mathrm{~nm}$, emission long-pass $590 \mathrm{~nm}$ ) were captured on cyan blue and red channels, respectively, of a true color image for each of nine evenly spaced fields per coverslip, and the proportion of total stained nuclei that did not stain with cell-impermeant propidium iodide was taken as the proportion of cells surviving. The method has the advantage (over the propidium iodide/fluorescein diacetate method) that relatively dense cells may be counted. At the excitation wavelengths used, pro- pidium iodide also stains protein to a small extent. This results in an occasional red rim around the blue nuclei of living cells and is resolved easily from double-stained magenta nuclei scored as dead. Data shown were obtained from between three and nine coverslips per condition. These coverslips were obtained, in each case, from two to three separate cell preparations.

In the graphs the term "\% dead cells" is the percentage of cells present scored as dead under basal conditions. "\% Protection" is defined as the increase in survival above control (i.e., $0 \%$ protection $=$ control survival), where $100 \%$ protection $=100 \%$ survival. This allows direct comparison of survival effects of compounds under different conditions for which the control survival is not constant.

Calcium measurements. Cells were loaded for $40^{\prime}$ in Modified Elliot's Medium (Courtney et al., 1990) containing $5 \mu \mathrm{M}$ Fluo-3/AM (Molecular Probes), $33 \mu \mathrm{g} / \mathrm{ml}$ BSA (Sigma), and $0.02 \%$ pluronic acid (Molecular Probes), washed five times in $\mathrm{Mg}^{2+}$-free Elliot's, and placed in a chamber heated to $37^{\circ} \mathrm{C}$ on the stage of a Nikon Diaphot microscope. Cells were excited at $480 \mathrm{~nm}$ through a $40 \times / 1.3$ N.A. objective, and emission light was passed through a DM 510 dichroic mirror and $520 \mathrm{~nm}$ barrier filter onto a 1000TE cooled CCD (Electrim). Images were collected once per second under the control of software developed by the authors. Data were analyzed with analysis software described previously (Lindqvist et al., 1995). Spontaneous calcium channel activity was recorded and then terminated by addition of $1 \mu \mathrm{M}$ nifedipine to the incubating medium where indicated in the figure. Single wavelength fluorescence values $(F)$ were converted to cytoplasmic-free $\left[\mathrm{Ca}^{2+}\right]$, as previously reported, with the formula $\left[\mathrm{Ca}^{2+}\right]=K_{\mathrm{D}} \times\left(F-F_{\min }\right) /\left(F_{\max }-F\right)$, using published $K_{\mathrm{D}}$ values (385 nM; Kao et al., 1989). Calibration values were obtained by using ionomycin in parallel experiments. The data shown were obtained from 7 DIV cells cultured in low $\mathrm{KCl}$; nifedipine-blocked spontaneous activity also was observed at earlier stages in development, although this activity developed from smaller, more sustained elevations to larger, transient elevations with increasing age in culture. Cells cultured in elevated $\mathrm{KCl}$ exhibited no detectable nifedipine-sensitive spontaneous calcium elevations.

Protein detection and quantitation. Levels of c-Fos and c-Jun were assessed by exposing cells for $2 \mathrm{hr}$ to $10 \mathrm{ng} / \mathrm{ml} \mathrm{NGF,} \mathrm{BDNF,} \mathrm{NT-3,} \mathrm{or}$ TNF or $10 \mathrm{nM}$ TPA and blotting the cell lysates with polyclonal anti-Fos antibody (Oncogene Science, Uniondale, NY) or monoclonal anti-c-Jun antibody (Transduction Labs, Lexington, KY), and film was exposed over the linear range by the ECL method, according to the manufacturer's instructions (Amersham International, Amersham, UK). Exposed films were digitized by flatbed scanning and quantitated by imaging software developed by the authors (Lindqvist et al., 1995). Changes in c-Fos immunoreactivity in elevated $\mathrm{KCl}$ were detected in a band $\sim 62 \mathrm{kDa}$; this band was quantitated. In low $\mathrm{KCl}$, changes were detected in a band $~ 55$ $\mathrm{kDa}$, and a $62 \mathrm{kDa}$ band could not be detected. Therefore, under these conditions the $55 \mathrm{kDa}$ band was quantitated. Rabbit polyclonal subtypespecific Trk 763, TrkB 794, and TrkC 798 from Santa Cruz Biotech (Santa Cruz, CA) were used for immunodetection of TrkA, TrkB, and TrkC, respectively. A TrkA-specific antiserum generously provided by Dr. Louis Reichardt (University of California, San Francisco) also was used. Rabbit antiserum 9651 raised to the ligand-binding sequences of p75 sequences, generously provided by Dr. Moses Chao (Cornell University Medical College, New York), was used for immunodetection of $\mathrm{p} 75^{\mathrm{NTR}}$ and for blocking NGF action via p $75^{\text {NTR }}$.

Immunocytochemistry. Immunocytochemical staining for $\mathrm{NF}-\kappa \mathrm{B}$ p 65 subunit was performed as described in Menon et al. (1993) by using 1:500 biotin anti-rabbit (Sigma) and 1:50 ExtrAvidin fluorescein (Sigma). Slides were examined under a Leica confocal microscope with a $100 \times$ objective.

\section{RESULTS}

\section{Cell death occurs in two phases}

We first determined the time course of cell death of cerebellar granule neurons in serum-containing culture. Hoechst 33342 is membrane-permeant and stains all nuclei, whereas propidium iodide is membrane-impermeant. Cell death is calculated as the proportion of nuclei present that stains with propidium iodide. This technique avoids many artifacts to which other methods are susceptible (Juurlink and Hertz, 1993). It detects damage to the plasma membrane and thus measures both necrotic and late apoptotic cells. Almost all of the cells scored as dead in the results 


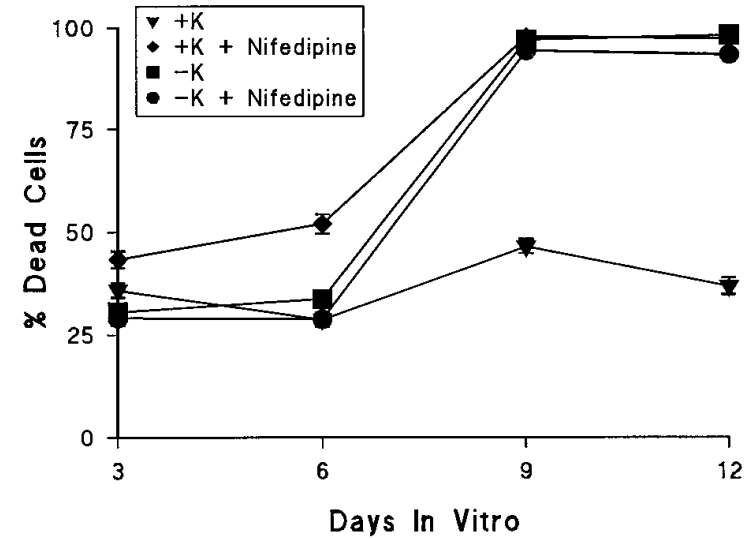

Figure 1. Cell death occurs in two phases: L-type voltage-sensitive calcium channels prevent only the late phase. Of the cells present at 3-6 d in vitro (DIV), 30-50\% were dead; the remaining cells died between 6 and 9 DIV. The early phase was not prevented by elevated $\mathrm{KCl}(+K)$. Elevated $\mathrm{KCl}$ in the absence of nifedipine prevented only the late phase of cell death.

that follow had pyknotic nuclei; the predominant mode of death described here, therefore, may be of an apoptotic nature. Figure 1 shows the percentage of dead cells present over the first 12 DIV. Cells were cultured in the absence or presence of $20 \mathrm{~mm}$ supplementary $\mathrm{KCl}$ and $1 \mu \mathrm{M}$ of the L-type voltage-sensitive calcium channel (VSCC) inhibitor nifedipine, as indicated. In agreement with previous results (Gallo et al., 1987), there is a requirement for depolarization for prolonged survival involving L-type VSCCs. However, a significant proportion of cells present even during the first 6 DIV are dead, and depolarization does not prevent this death.

\section{Protection from basal cell death by neurotrophins, TNF, and TPA}

BDNF enhances survival of cerebellar granule neurons in serumfree culture (Segal et al., 1992; Lindholm et al., 1993; Gao et al., 1995). However, depolarization has been reported not to enhance survival under these conditions (Kingsbury et al., 1985), and maturation is abrogated to the extent that amino acid carriers are not expressed and stimulus-coupled transmitter release does not occur or is delayed (Balazs et al., 1988a). As depolarization dependence begins after 6 DIV, we asked whether activation of neurotrophin receptors regulates the early phase of cell survival.

Figure 2 shows the percentage of cells present scored as dead at $6 \mathrm{DIV}$ in cultures incubated with the dimeric neurotrophins NGF or BDNF from 1 DIV. In cultures incubated with neurotrophinsupplemented elevated $\mathrm{KCl}$ medium alone (left set of columns), $\sim 38 \%$ of the cells are dead in controls. NGF moderately but significantly reduces this proportion, and BDNF more strongly reduces cell death. In parallel experiments increasing amounts of 9651 rabbit anti-p75, an antiserum that binds the ligand-binding site of $\mathrm{p} 75^{\mathrm{NTR}}$ (Huber and Chao, 1995), were included. At 1:200 dilution (right set of columns), NGF no longer reduces cell death, whereas BDNF is still protective. This suggests that binding of NGF to $\mathrm{p} 75^{\mathrm{NTR}}$ is essential for NGF-evoked reduction of cell death, whereas BDNF is able to reduce death independent of binding to $\mathrm{p} 75^{\mathrm{NTR}}$. The $\mathrm{p} 75^{\mathrm{NTR}}$ antiserum alone reduces cell death. This would be consistent with the divalent $\mathrm{p} 75^{\mathrm{NTR}}$ antibodies mimicking the NGF-evoked reduction in death and a component of the BDNF-evoked reduction in death. Thus NGF

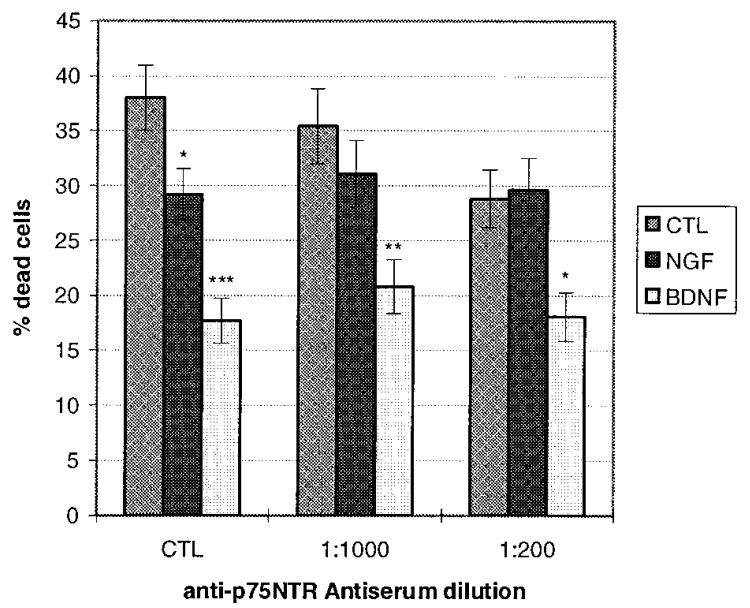

Figure 2. Neurotrophic factors protect from cell death at 6 DIV. Antiserum to $\mathrm{p} 75^{\mathrm{NTR}}$ ligand-binding domain prevents NGF-evoked protection. Shown is quantitation of the protective effects of the neurotrophins NGF and BDNF on cerebellar granule neuron cultures. NGF and BDNF both reduce cell death. Increasing amounts of antiserum raised against the ligand-binding domain of p $75^{\mathrm{NTR}}$ prevent NGF-evoked survival promotion and reduce basal death without effect on survival in the presence of BDNF.

has no further effect above that of the antiserum, and BDNF has a smaller effect than in the absence of antiserum.

The neurotrophic factors NGF, BDNF, and NT-3 would be expected to activate their respective Trk receptors, if present, and the nonselective $\mathrm{p} 75^{\mathrm{NTR}}$. $\mathrm{p} 75^{\mathrm{NTR}}$ is a member of the TNF receptor family (Mahadeo et al., 1994) that exhibits common structural and signaling features. Trks activate a number of signaling cascades, including protein kinase C (PK-C) via PL-C $\gamma$ (Vetter et al., 1991) and the MAP kinase cascade via Ras (Ohmichi et al., 1992). TPA also activates PK-C, which has been reported to activate the MAP kinase cascade via Raf (Kolch et al., 1993). Therefore, we tested NGF, BDNF, and NT-3 while attempting to mimic the actions of $\mathrm{p} 75^{\mathrm{NTR}}$ activation with TNF and to activate specific components of Trk signaling with TPA.

Cells were cultured in the absence or presence of $20 \mathrm{~mm}$ supplementary $\mathrm{KCl}$. Then neurotrophins, TNF- $\alpha$, TPA, and $1 \mu \mathrm{M}$ nifedipine were introduced during the medium change at 1 DIV. Because the basal level of death in the absence of neurotrophins was not identical in the different conditions of depolarization and nifedipine (see Fig. 1), protection from death by neurotrophins was normalized to the maximum possible reduction in death in each condition of depolarization and nifedipine (see Materials and Methods).

NGF, BDNF, NT-3, and TNF protected against cell death (Fig. $3 A$ ). The modest protective effects of NGF and TNF were eliminated by culturing the cells in low $\mathrm{KCl}$ in the presence of nifedipine, conditions expected to reduce VSCC activity to a minimum. The greater protection evoked by BDNF and NT-3 was reduced only partially under such conditions. Ceramide is a putative mediator of $\mathrm{p} 75^{\mathrm{NTR}}$ and TNF-R signaling (Yanaga and Watson, 1992; Dobrowsky et al., 1995). Thus we investigated the protective effects of the water-soluble analog $\mathrm{C}_{2}$ ceramide on cells cultured in elevated $\mathrm{KCl}$, which are sensitive to protection by $\mathrm{NGF}$ and TNF. Low concentrations of $\mathrm{C}_{2}$ ceramide protected cells against death to a similar extent to NGF and TNF (Fig. 3B). At $10 \mu \mathrm{M}$, ceramide had no effect, whereas $100 \mu \mathrm{M}$ caused the death of all the cells in the culture (data not shown). 
A

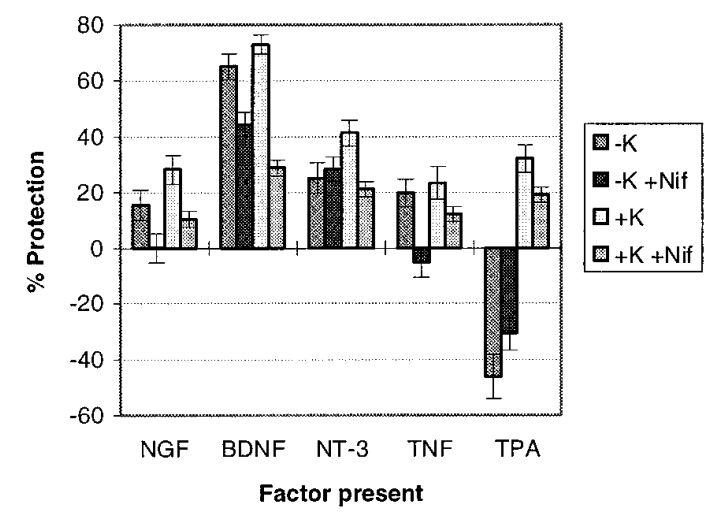

B

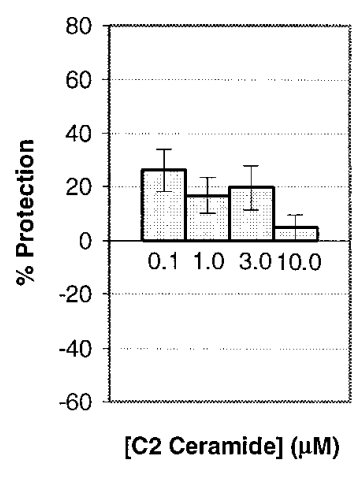

C

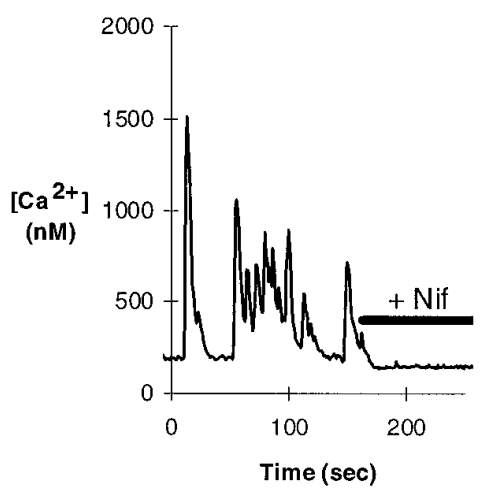

Figure 3. Neurotrophic factors, TNF, TPA, and ceramide protect from cell death at 6 DIV. A, Quantitation of the protective effects of neurotrophins, $\mathrm{TNF}$, and TPA on cerebellar granule neuron cultures. NGF, BDNF, NT-3, and TNF all evoke protection against cell death. In elevated $\mathrm{KCl}(+K), 1 \mu \mathrm{M}$ nifedipine $(+N i f)$ reduces the protective effects, and $10 \mathrm{nM}$ TPA behaves like a neurotrophin. In low $\mathrm{KCl}(-K)$, nifedipine eliminates protection by NGF and TNF, but not BDNF or NT-3. Under these conditions $10 \mathrm{nM}$ TPA is toxic. All other conditions significantly $(p<0.05)$ protect against cell death. $B, \mathrm{C}_{2}$ ceramide at $0.1-3.0 \mu \mathrm{M}$ protects cells cultured in elevated $\mathrm{KCl}$ against cell death to a similar extent to NGF and TNF. Higher concentrations do not protect against cell death. $C$, Spontaneous cytoplasmic-free calcium elevations exist in cells cultured in low $\mathrm{KCl}$. These elevations are blocked by addition of $1 \mu \mathrm{M}$ nifedipine.

Although nifedipine might be expected to be effective only when elevated $\mathrm{KCl}$ is present to depolarize the neurons, cerebellar granule neurons cultured in low $\mathrm{KCl}$ can be observed to undergo spontaneous VSCC activity that is blocked by nifedipine (Fig. 3C); such activity is not observed in cells cultured in elevated $\mathrm{KCl}$ (Courtney et al., 1990). Furthermore, these neurons undergo spontaneous L-type and N-type VSCC activity in culture medium (Doherty et al., 1991). Thus it is likely that nifedipine modulates the actions of neurotrophins via L-type VSCCs, even in low $\mathrm{KCl}$ conditions. These results suggest that NGF and TNF act by mechanisms dependent on L-type VSCC activity, whereas BDNF and NT-3 act via an additional mechanism that is independent of VSCC activity. TPA was protective to cells cultured in the presence of elevated $\mathrm{KCl}$, but, unlike the other factors tested, it was toxic to cells cultured in low $\mathrm{KCl}$.

Figure 4 shows representative fields of cells used in these studies. Figure $4 A$ shows phase-contrast images of cells in the absence or presence of elevated $\mathrm{KCl}$ at 6 DIV. In Figure $4 B$, cells stained by the cell death quantitation technique that was used are shown. The proportion of dead cells (with double-stained nuclei) at 6 DIV was not altered significantly by the presence of elevated $\mathrm{KCl}$; however, at $9 \mathrm{DIV}$ virtually all cells were dead unless the culture medium was supplemented with elevated $\mathrm{KCl}$. It should be noted that the proportion of dead cells at any time point is an underestimation of the total death of cells up to that time, because cells that had died at earlier time points continue to degenerate and are lost from the culture surface (Xia et al., 1995). Representative fields of cells at 6 DIV cultured with BDNF or TPA in low $\mathrm{KCl}$ are shown in Figure $4 C$. Under these conditions BDNF reduced cell death, whereas TPA notably increased it.

\section{Cerebellar granule neurons express TrkB and $p 75^{\mathrm{NTR}}$, but not TrkA, receptors}

To understand the mechanism of action of the neurotrophins, we determined which neurotrophin receptor subtypes were expressed in cerebellar granule neurons under the conditions in which neurotrophins had been added. Lysates of cells cultured in low or elevated $\mathrm{KCl}$ were probed with specific polyclonal antibodies (Fig. $5 A$ ). Intense staining at $\sim 145 \mathrm{kDa}$ was obtained with the anti-
TrkB antibody. A faint band could be detected with prolonged exposure to the anti-TrkC immunoblot. However, no band was detectable with the anti-TrkA. A polyclonal antiserum raised to the extracellular domain of TrkA (Clary et al., 1994) also was tested. This antiserum detected TrkA (140 kDa) in PC12 extracts, but no comigrating band was detected in granule neuron extracts (data not shown). Slight cross-reactivity was observed with a more slowly migrating band, probably $145 \mathrm{kDa}$ TrkB. We also detected $\mathrm{p} 75^{\mathrm{NTR}}$ protein in cerebellar granule lysates (Fig. $5 B$ ) with the polyclonal antibody [9651] used in Figure 2, consistent with previous reports of mRNA for $\mathrm{p} 75^{\mathrm{NTR}}$ in these neurons in culture (Lindholm et al., 1993; Segal et al., 1995) and early during development in vivo (Huber and Chao, 1995).

\section{Regulation of immediate early gene product levels and NF- $\kappa$ B localization by neurotrophins, TNF, and TPA}

Trks induce Ras-mediated activation of the MAP kinase cascade (Ohmichi et al., 1992), increasing transcription of the immediate early gene (IEG) c-fos (Cordon-Cardo et al., 1991). On the other hand, in some cells p $75^{\mathrm{NTR}}$ and TNF receptors activate JNK (Kyriakis et al., 1994; Casaccia-Bonnefil et al., 1996), a kinase that leads to increased $c$-jun transcription and c-Jun stability (for review, see Kyriakis et al., 1995; Musti et al., 1997).

To investigate whether these cascades might be activated as a result of exposure to neurotrophins at $1 \mathrm{DIV}$, we measured the levels of c-Fos and c-Jun in cells stimulated with NGF, BDNF, NT-3, TNF, or TPA by immunoblot densitometry. A 2 hr exposure was chosen because the levels of these proteins clearly are elevated after this time (our unpublished observations). In elevated $\mathrm{KCl}, \mathrm{BDNF}, \mathrm{NT}-3$, and TPA elevated c-Fos levels, whereas neither NGF nor TNF increased c-Fos (Fig. 6A). In low $\mathrm{KCl}$, BDNF still detectably increased c-Fos levels, but the other treatments did not. Given the presence of TrkB protein and the absence of TrkA, these results are consistent with BDNF elevating c-Fos levels via TrkB and presumably the MAP kinase cascade. TPA also may be acting via this pathway (Kolch et al., 1993).

In elevated $\mathrm{KCl}, \mathrm{NGF}, \mathrm{BDNF}$, and TPA also increased c-Jun levels; neither NT-3 nor TNF detectably changed c-Jun levels (Fig. $6 B$ ). The absence of elevated $\mathrm{KCl}$ eliminated the response to 
A

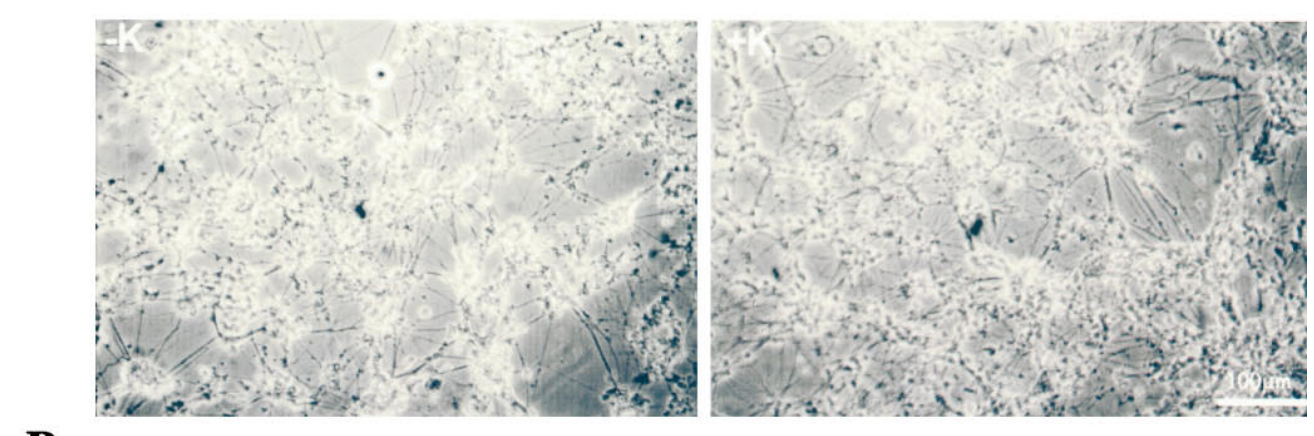

B
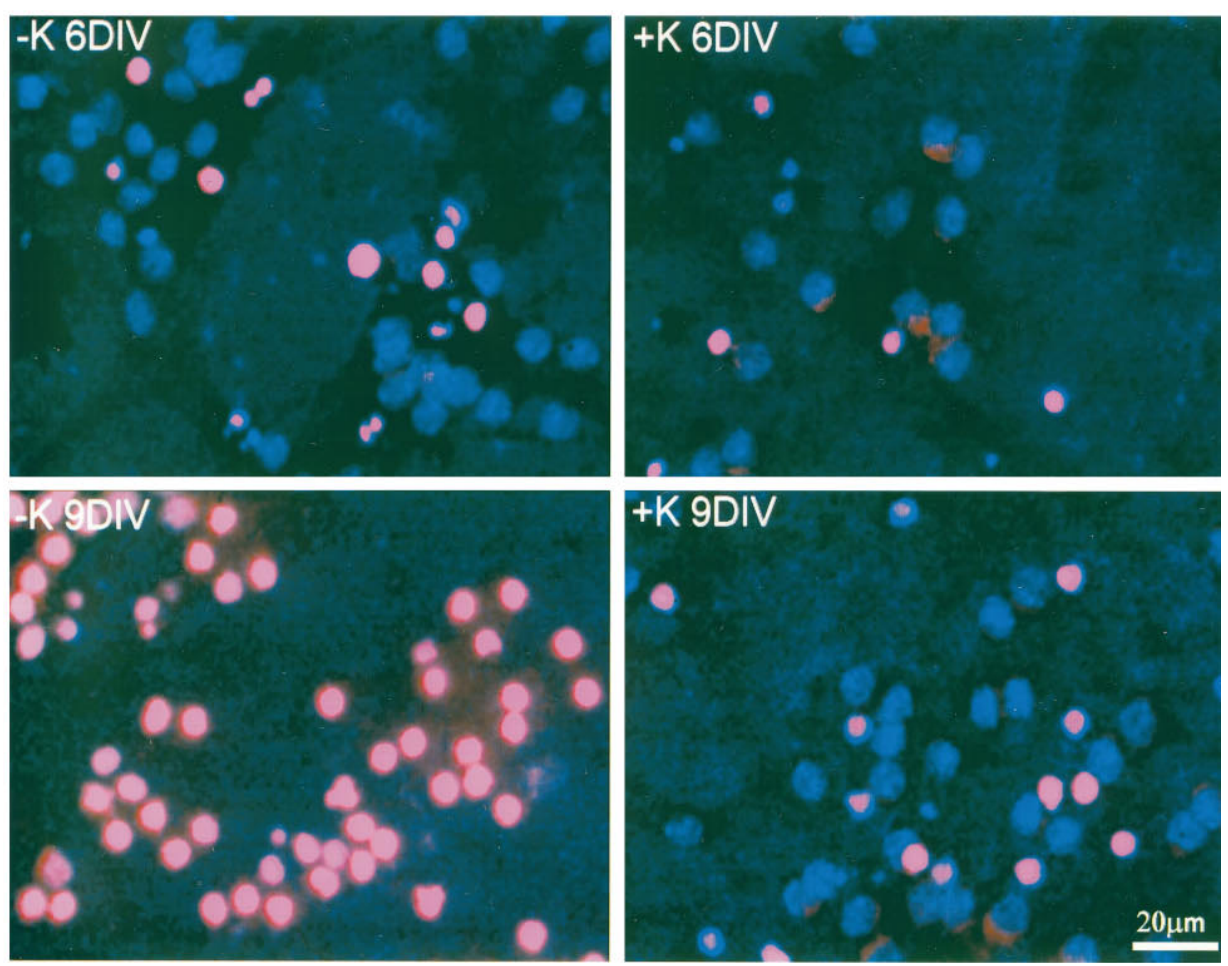

C
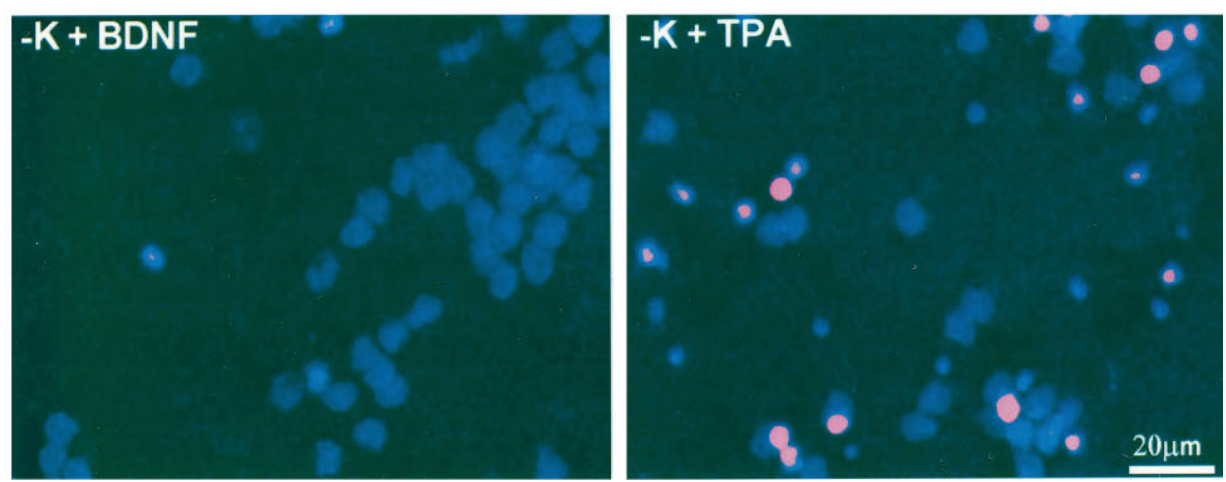

Figure 4. Representative fields of cerebellar granule neuron cultures in phase-contrast mode and in fluorescence mode after exposure to Hoechst 33342 and propidium iodide. $A$, Phase-contrast images of cerebellar granule neuron cultures at low magnification are shown. Left, Cells cultured in low $\mathrm{KCl}$ $(-K)$ are shown. Right, Cells are cultured in elevated $\mathrm{KCl}(+K) . B$, The presence of elevated $\mathrm{KCl}(+K)$ in the culture medium does not alter significantly the proportion of cells with double-stained nuclei at 6 DIV (upper pair). However, by 9 DIV virtually all nuclei double stain, i.e., are dead, unless supplementary $\mathrm{KCl}$ is present (lower pair). $C$, Representative fields of cells cultured in low $\mathrm{KCl}(-K)$ stained at 6 DIV. Under these conditions $10 \mathrm{ng} / \mathrm{ml}$ BDNF protects from cell death, whereas $10 \mathrm{nM}$ TPA is toxic. 
$\mathbf{A}$

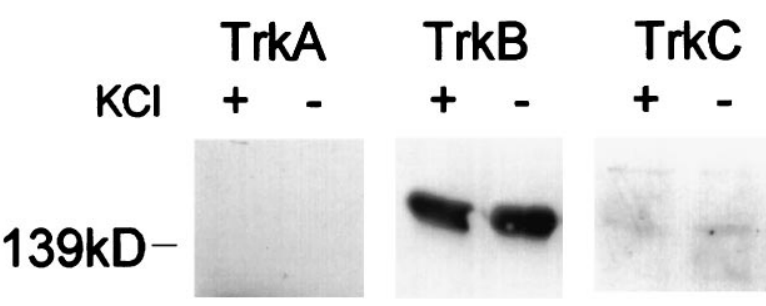

B

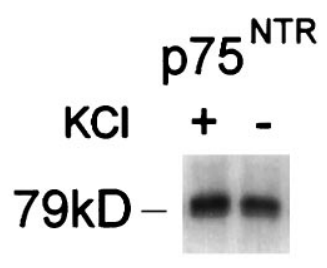

Figure 5. Neurotrophin receptors in cerebellar granule neuron cultures. $A$, Cerebellar granule neurons at 1 DIV express TrkB, the selective receptor for BDNF, but not TrkA. Slight immunoreactivity to anti-TrkC at the appropriate molecular weight is detectable after prolonged exposure of film. $B$, Cerebellar granule neurons at 1 DIV express p $75^{\mathrm{NTR}}$, the nonselective neurotrophin receptor.

NGF and partially reduced the response to BDNF, whereas the response to TPA was unchanged. Although TNF did not alter IEG levels detectably at 1 DIV, we have observed c-Jun elevations in response to TNF in 3 DIV cells (data not shown). These results are consistent with NGF acting via a non-Trk receptor, presumably $\mathrm{p} 75^{\mathrm{NTR}}$, whereas BDNF acts at least in part via a separate, presumably TrkB-mediated, pathway.

$\mathrm{p} 75^{\mathrm{NTR}}$ and TNF-R activation have been reported to evoke nuclear translocation of NF- $\kappa$ B (Yang et al., 1993; Carter et al., 1996a), which recently has been shown to have an antiapoptotic role (Liu et al., 1996). Therefore, we investigated whether the survival-promoting factors that were used evoked translocation of the p65 subunit of NF- $\kappa$ B. Confocal microscopy of immunostained cerebellar granule neurons revealed no bulk translocation of the NF- $\kappa$ B p 65 subunit into the nucleus on stimulation with the survival-promoting factors tested (Fig. 6C). However, some constitutive nuclear staining, consistent with a previous report (Guerrini et al., 1995), could be detected under all conditions.

\section{Inhibitor studies}

These data suggest that two different mechanisms may mediate the signaling and survival-promoting effects of NGF and BDNF. Because distinct protein kinases may be involved, the effects of kinase inhibitors on the actions of these two factors on cells cultured in elevated $\mathrm{KCl}$ were compared.

\section{Wortmannin does not affect basal survival or BDNF-evoked survival promotion}

Phosphatidylinositol-3 kinase (PI-3K) is a prominent kinase activated by tyrosine kinase receptors, including Trks, and has been proposed to mediate NGF-evoked survival of neuronally differentiated PC12 cells (Yao and Cooper, 1995). Therefore, we investigated whether inhibition of PI-3K with the specific inhibitor wortmannin (Okada et al., 1994) altered basal or neurotrophinpromoted survival. Wortmannin (100 nM) at 1 DIV had no significant effect on basal cell death at 6 DIV, nor did it prevent survival promotion by BDNF (Fig. 7). However, NGF did not improve survival significantly in the presence of this inhibitor.
Thus it is unlikely that wortmannin does not inhibit BDNFevoked survival as a result of low stability. Furthermore, BDNF has a clear survival-promoting effect within $24 \mathrm{hr}$ of addition (data not shown), and TrkB may, in fact, desensitize within this time period (Carter et al., 1995). Thus BDNF-induced survival does not depend on wortmannin-sensitive PI-3Ks.

\section{$P K-C$ activity is absolutely required for NGF-evoked survival promotion and partly required for full BDNF-evoked survival promotion}

PK-C previously has been attributed a mediator role in BDNFevoked survival in cerebellar granule neurons cultured in serum-free medium (Zirrgiebel et al., 1995). Using the specific PK-C inhibitor bisindolylmaleimide GF 109203X (Toullec et al., 1991), we investigated the role of PK-C in basal survival and neurotrophin-evoked survival promotion in neurons cultured with serum (Fig. 7). Survival under basal conditions was not altered by PK-C inhibition. This suggests that the responses observed to $10 \mathrm{~nm}$ TPA were attributable to activation and not to downregulation of PK-C. In further support of this, survival promotion in elevated $\mathrm{KCl}$ also was observed with 1 nM TPA (data not shown). In the presence of the PK-C inhibitor, NGF significantly reduces survival, suggesting, first, that the protective effect of NGF is dependent on PK-C and, second, that NGF induces some event that is toxic to the cells, at least in the absence of PK-C activity. The protective effect of BDNF is reduced only partially by the PK-C inhibitor.

The nonselective kinase inhibitor $\mathrm{K} 252 \mathrm{a}$ is used frequently to suggest that neurotrophin responses are Trk-mediated. However, this inhibitor is known to have nanomolar $\mathrm{IC}_{50}$ values against PK-A, PK-G, and PK-C (Kase et al., 1987) and is even more potent against phosphorylase kinase and CaM kinase II than it is against Trks (Elliott et al., 1990; Hashimoto et al., 1991; Tapley et al., 1992). Another inhibitor of CaM kinase II potently reduces basal survival in these cells (our unpublished observations); consistent with this, K252a compromised basal survival at concentrations as low as $10 \mathrm{~nm}$, under which conditions BDNF still clearly promoted survival (data not shown). This inhibitor thus is not useful in dissecting the survival responses reported here.

The survival promotion evoked by NGF as a proportion of the cell population is rather modest. Thus we sought conditions under which the signaling evoked by NGF might be more limiting under basal conditions to potentiate survival promotion by NGF. The tumor suppressor curcumin antagonizes the DNA-binding activity of c-Jun ( $\mathrm{IC}_{50} \sim 20 \mu \mathrm{M}$; Huang et al., 1991) and inhibits NF- $\kappa \mathrm{B}$ translocation $\left(\mathrm{IC}_{50}<40 \mu \mathrm{M}\right.$; Singh and Aggarwal, 1995). Both NGF and BDNF increased the levels of c-Jun, and p75 ${ }^{\text {NTR }}$ activation by NGF has been reported to translocate NF- $\kappa \mathrm{B}$ (Carter et al., 1996a), which has been attributed with an antiapoptotic function. Because we detected constitutive levels of c-Jun and of nuclear NF- $\kappa \mathrm{B}$ immunoreactivity (Fig. $6 B, C$ ), we investigated whether partial AP-1/NF- $\kappa \mathrm{B}$ antagonism with curcumin might cause the basal levels of c-Jun and translocated NF- $\kappa$ B to be more limiting, thus potentiating survival-promotion via these pathways. The addition of $100 \mu \mathrm{M}$ curcumin completely eliminated survival of cerebellar granule neurons in the presence or absence of NGF or BDNF (data not shown). However, $10 \mu \mathrm{M}$ curcumin increased basal death to only $50 \%$ (Fig. 7). Under these conditions both $\mathrm{NGF}$ and BDNF evoked clear reductions in death, amounting to $>20$ and $35 \%$ of the cells present, respectively. 
A

\section{c-Fos levels}

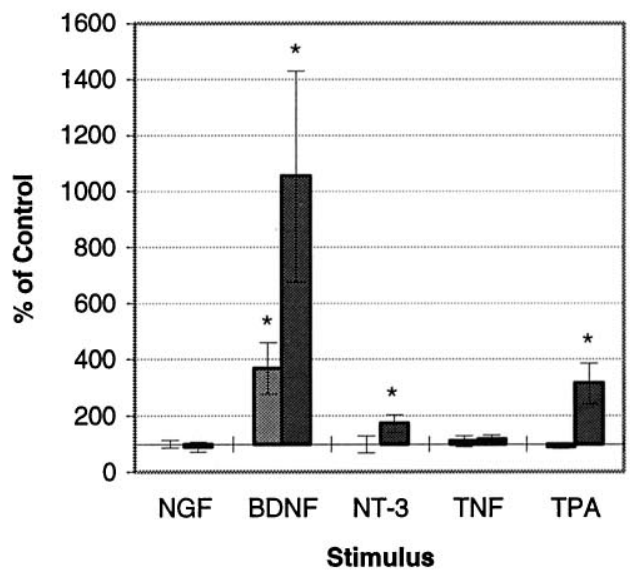

B

\section{c-Jun levels}

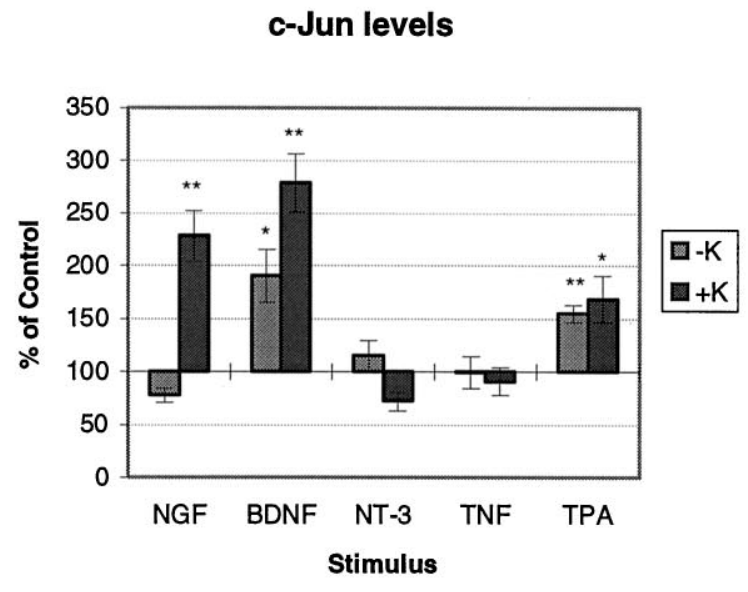

C

Control

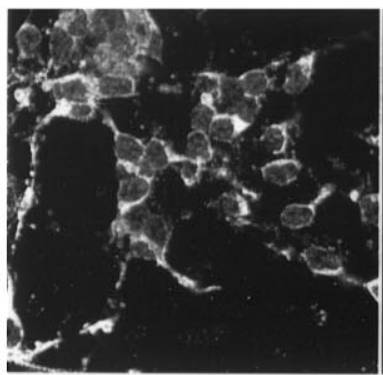

TNF- $\alpha$

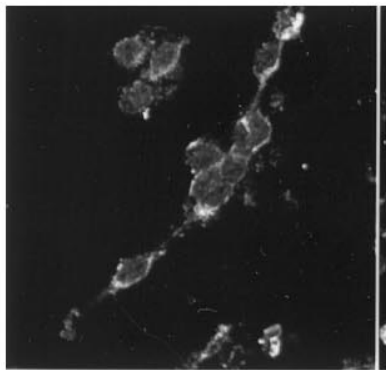

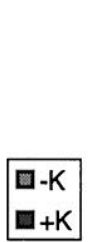

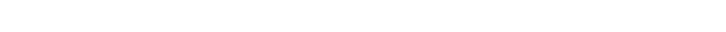




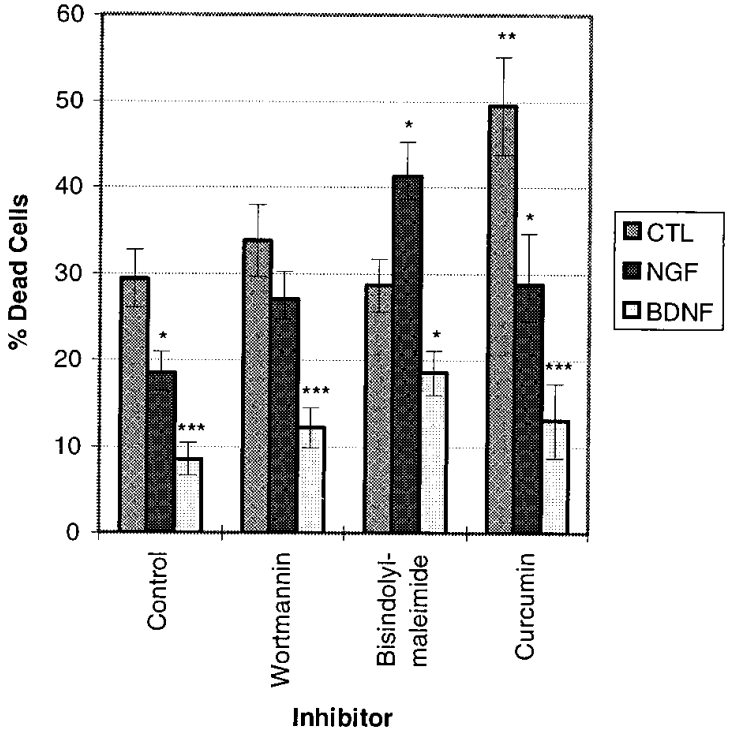

Figure 7. Effects of specific inhibitors on basal and neurotrophinenhanced survival. Cells were cultured in the presence of elevated potassium and either no neurotrophin, NGF, or BDNF $(10 \mathrm{ng} / \mathrm{ml})$ and no inhibitor (Control), wortmannin (100 nM), bisindolylmaleimide $(1 \mu \mathrm{M})$, or curcumin $(10 \mu \mathrm{M})$. Neither wortmannin nor bisindolylmaleimide altered basal cell death, but in the presence of bisindolylmaleimide NGF became toxic and BDNF-evoked protection was reduced. Curcumin increased basal cell death, revealing enhanced protection by the neurotrophins. ${ }^{*} p<$ 0.02 and ${ }^{* * *} p<0.001$ indicate significant difference, as compared with death with the same inhibitor and no neurotrophin; ${ }^{* *} p<0.01$ indicates significant difference, as compared with the corresponding inhibitor-free control.

\section{DISCUSSION}

Our study investigates specific signaling mechanisms in neurotrophin-evoked survival-promotion in cerebellar granule neurons during the first week in culture. Considerable cell death occurs during this period. Unlike the delayed phase of cell death, this death is not reduced by inhibition of VSCC activity (Fig. 1). This allowed us to investigate alternative signaling mechanisms, such as those evoked by the neurotrophins, in the survival of these CNS neurons.

\section{NGF and BDNF promote survival of cerebellar granule neurons via two distinct signaling mechanisms}

The NGF-evoked and TNF-evoked protection against basal death can be eliminated by VSCC inhibition. In contrast, part of the protection evoked by BDNF and NT-3 persists during VSCC inhibition (Fig. 3A). The simplest explanation is that NGF and TNF act via the same pathway, whereas BDNF and NT-3 act in part via this mechanism and in part by an independent pathway. Neurotrophins act via specific Trk receptors and the nonselective $\mathrm{p} 75^{\mathrm{NTR}}$. The model proposed corresponds to NGF acting exclusively via $\mathrm{p} 75^{\mathrm{NTR}}$, whereas BDNF and NT-3 act both via this receptor and via a Trk receptor; hence, there are two components of protection resolved by VSCC modulation. TNF would act via its own receptor, known to be structurally and functionally homologous to $\mathrm{p} 75^{\mathrm{NTR}}$. The finding that anti-p $75^{\mathrm{NTR}}$ antiserum, which blocks NGF binding, prevents and even mimics NGFevoked survival promotion (Fig. 2) supports this interpretation.

The presence of an antimitotic ensured that cell counts reflected changes in survival and not proliferation. The cultures used consist of $>90 \%$ granule neurons, and no increases in contaminating cell types were detected that could account for the modest protection evoked by NGF and TNF (see Materials and Methods). Furthermore, the increased effectiveness of NGF in the presence of curcumin (Fig. 7) strongly suggests that the major cell type, i.e., the cerebellar granule neuron, is responsible for the survival promotion that was observed.

\section{Testing the two-component model}

TrkB protein and $p 75^{N T R}$ are present, but TrkA is undetectable

We detected TrkB, the specific receptor for BDNF, in cerebellar granule neuron lysates, whereas TrkA, the specific receptor for NGF, was undetectable (Fig. 5). This is consistent with the detection of $\operatorname{trk} B$, but not $\operatorname{trk} A$, mRNA reported previously (Segal et al., 1992; Lindholm et al., 1993). The faint TrkC immunoreactivity detected may represent cross-reactivity with TrkB; however, TrkC protein probably is present because NT-3 induces tyrosine phosphorylation in these cells of a pan-Trk-immunoprecipitable band migrating more slowly than TrkB (Segal et al., 1995). NT-3 binds to and activates TrkB at the concentrations used here (Soppet et al., 1991) and thus may be expected to mimic BDNF even in the absence of TrkC. Because p $75^{\mathrm{NTR}}$ was detected, consistent with the reported detection of mRNA for $\mathrm{p} 75^{\mathrm{NTR}}$ (Segal et al., 1995), NGF presumably is acting via this receptor. This suggests that the actions of NGF are mediated entirely by $\mathrm{p} 75^{\mathrm{NTR}}$, hence the similarity in survival promotion to that evoked by TNF. BDNF would be expected to act via both TrkB and $\mathrm{p} 75^{\mathrm{NTR}}$.

\section{Regulation of c-Fos and c-Jun}

Trks, unlike p $75^{\mathrm{NTR}}$, increase the expression of $c$-fos mRNA via the MAP kinase cascade (Cordon-Cardo et al., 1991; Ohmichi et al., 1992). Consistent with the presence of TrkB, but not TrkA, BDNF elevates c-Fos levels, whereas NGF does not (Fig. 6A). p $75^{\text {NTR }}$ has been reported to activate JNK (Casaccia-Bonnefil et al., 1996), which increases c-jun transcription and c-Jun stability (for review, see Kyriakis et al., 1994; Musti et al., 1997). The role of Ras activators such as Trks in JNK activation is controversial (Minden et al., 1994; Xia et al., 1995) (see also Masuelli and Cutler, 1996). Thus both NGF and BDNF might be expected to activate JNK via $\mathrm{p} 75^{\mathrm{NTR}}$, whereas BDNF might induce additional activation via TrkB/Ras. Our results are consistent with these predictions, increases in c-Jun being induced by NGF and BDNF. $\mathrm{NGF}$ does not elevate c-Jun levels in low $\mathrm{KCl}$, whereas BDNF again is only partially sensitive to this condition that eliminates the NGF response, supporting our interpretation that BDNF acts via two independent pathways.

\section{Mediators of $\mathbf{p} 75^{\mathrm{NTR}} / \mathrm{TNF}-\mathrm{R}$ regulation of survival}

Ligand binding to $\mathrm{p} 75^{\mathrm{NTR}}$ may promote cell death (CasacciaBonnefil et al., 1996; Frade et al., 1996) or survival (Rabizadeh et al., 1993; Cortazzo et al., 1996). This is also the case for TNF-R. Both receptors evoke similar signaling events, including JNK activation (Kyriakis et al., 1994; Casaccia-Bonnefil et al., 1996) and the NF- $\kappa$ B pathway (Yang et al., 1993; Carter et al., 1996a). TNF-evoked death occurs via a TRAF2-independent TRADDFADD pathway (Hsu et al., 1996). Similar zinc finger proteins may associate with p $75^{\mathrm{NTR}}$ (Carter et al., 1996b). The potentiation of NGF survival promotion by curcumin is consistent with an essential requirement for some c-Jun and/or NF- $\kappa \mathrm{B}$ for survival, although curcumin also may be acting on other targets, especially when present at $100 \mu \mathrm{M}$. TNF-R and $\mathrm{p} 75^{\mathrm{NTR}}$ also activate sphingomyelinase/ceramide signaling (Yanaga and Watson, 1992; Dobrowsky et al., 1995), which may activate JNK (Westwick et al., 1995). Ceramide may be responsible for the NGF-evoked and 
TNF-evoked survival promotion, because exogenous $\mathrm{C}_{2}$ ceramide also promotes survival of cerebellar granule neurons (Fig. $3 B$ ), as it does in sympathetic neurons (Ito and Horigome, 1995).

JNK and c-Jun activation have been proposed to mediate apoptosis (Ham et al., 1995; Xia et al., 1995; Cuvillier et al., 1996; Verheij et al., 1996). However, a noncytotoxic TRAF2-mediated pathway activates JNK and NF- $\kappa \mathrm{B}$ in response to TNF (Natoli et al., 1997). In many cases, activation of c-Jun and the JNK pathway correlates with cell maturation (Pulverer et al., 1993; Su et al., 1994; Berberich et al., 1996; Heasley et al., 1996) and protection from apoptosis (Hallahan et al., 1995; Sakata et al., 1995; Johnson et al., 1996) Indeed, the JNK activator SEK1 mediates survival in T-cell development (Nishina et al., 1997). The elevation of c-Jun levels correlates with protection against early cell death in cerebellar granule neurons.

NF- $\kappa$ B may be antiapoptotic (Beg and Baltimore, 1996; Liu et al., 1996; Van Antwerp et al., 1996; Wang et al., 1996), although it has been proposed to mediate glutamate-evoked death of mature cerebellar granule neurons (Grilli et al., 1996). We did not observe translocation of the p65 subunit of NF- $\kappa$ B on activation of survival-promoting pathways in cerebellar granule neurons (Fig. $6 C)$. However, we cannot exclude $\mathrm{NF}-\kappa \mathrm{B}$ as a mediator of neuroprotection in cerebellar granule neurons, because multiple $\mathrm{NF}-\kappa \mathrm{B}$ isoforms exist. Furthermore, it may be that only a small proportion, below our detection limit, of cellular NF- $\kappa \mathrm{B}$ need translocate to the nucleus (Gilmore, 1996) for protection to occur.

Measurements of IEG regulation indicate which signaling events can be evoked by the factors and their dependence on depolarization. However the rapid responses at 1 DIV should not be expected to explain all the survival-promoting effects observed 5 d later. For example, not NGF nor TNF nor NT-3 has any detectable effect at $2 \mathrm{hr}$ in low $\mathrm{KCl}$, although each still evokes survival-promotion by 6 DIV. It may be possible that gradual changes not detectable within 2 hr at 1 DIV are evoked, perhaps as a result of developmental changes in receptor expression or spontaneous calcium channel activity. Thus some of the survival promotion does not seem to require increases in c-Fos or c-Jun at such early time points. Although c-Fos is reported to have a short half-life and rapidly downregulate its own expression (SassoneCorsi et al., 1988) (see also Thompson et al., 1995), we have observed that BDNF addition to cerebellar granule neuron cultures at 1 DIV causes a prolonged elevation of c-Fos protein levels (Coffey et al., 1995).

\section{The role of PK-C in survival}

PK-C activity is required for both NGF-evoked survival and a component of BDNF-evoked survival (Fig. 7). This is again consistent with BDNF acting in part via a pathway that also is activated by NGF and in part by an independent pathway. Basal survival is unaffected, suggesting that basal and neurotrophinevoked survival mechanisms are distinct, and furthermore that any endogenous neurotrophins present do not enhance basal survival. However, this requirement for PK-C activity does not indicate necessarily that NGF activates PK-C in these cells or that this is the mechanism of survival promotion; this is unlikely, given the toxicity of TPA in low $\mathrm{KCl}$. In the presence of the PK-C inhibitor the addition of NGF increases cell death (Fig. 7). PK-C prevents apoptosis-associated DNA fragmentation evoked by ceramide (Obeid et al., 1993), which may accumulate on activation of p $75^{\text {NTR }}$ (Dobrowsky et al., 1994, 1995). Thus basal PK-C activity protects against such an $\mathrm{NGF} / \mathrm{p} 75^{\mathrm{NTR}}$-evoked signal that is otherwise toxic, as proposed for TNF receptors (Cuvillier et al.,
1996). Because BDNF also seems to act via $\mathrm{p} 75^{\mathrm{NTR}}$, this would explain the sensitivity of BDNF-evoked survival promotion to PK-C inhibitors we and others (Zirrgiebel et al., 1995) observed. Components of the serum-based medium might be responsible for elevating basal PK-C activity sufficiently to allow NGF to be survival-promoting, explaining why NGF-promoted survival has not been detected in this cell type in serum-free conditions (Segal et al., 1992; Lindholm et al., 1993; Gao et al., 1995).

In summary, NGF activates signal cascades in cerebellar granule neuronal cultures, leading to the elevation of c-Jun levels, and enhances survival in the absence of TrkA protein in a manner blocked by anti-p $75^{\text {NTR }}$ antiserum, suggesting a trophic role for $\mathrm{p} 75^{\mathrm{NTR}}$. BDNF is also protective, acting via an additional independent pathway likely to be via TrkB, which is expressed by the cells. PK-C inhibition reduces BDNF-evoked survival promotion and unmasks $\mathrm{NGF} / \mathrm{p} 75^{\mathrm{NTR}}$-evoked cell death without affecting basal survival in the absence of neurotrophins. Thus three distinct survival mechanisms in these cells are resolved: a basal neurotrophin-independent mechanism, an NGF/BDNF-evoked calcium-sensitive mechanism, and a further mechanism evoked by BDNF, but not NGF.

\section{REFERENCES}

Balazs R, Gallo V, Kingsbury A (1988a) Effect of depolarization on the maturation of cerebellar granule cells in culture. Brain Res 468:269-276.

Balazs R, Hack N, Jorgensen OS (1988b) Stimulation of the $N$-methylD-aspartate receptor has a trophic effect on differentiating cerebellar granule cells. Neurosci Lett 87:80-86.

Balazs R, Jorgensen OS, Hack N (1988c) $N$-methyl-D-aspartate promotes the survival of cerebellar granule cells in culture. Neuroscience 27:437-451.

Balazs R, Hack N, Jorgensen OS (1990) Interactive effects involving different classes of excitatory amino acid receptors and the survival of cerebellar granule cells in culture. Int J Dev Neurosci 8:347-359.

Beg AA, Baltimore D (1996) An essential role for NF- $\kappa \mathrm{B}$ in preventing TNF- $\alpha$-induced cell death. Science 274:782-784.

Berberich I, Shu G, Siebelt F, Woodgett JR, Kyriakis JM, Clark EA (1996) Cross-linking CD40 on B cells preferentially induces stressactivated protein kinases rather than mitogen-activated protein kinases. EMBO J 15:92-101.

Carter BD, Zirrgiebel U, Barde YA (1995) Differential regulation of $\mathrm{p} 21^{\text {ras }}$ activation in neurons by nerve growth factor and brain-derived neurotrophic factor. J Biol Chem 270:21751-21757.

Carter BD, Kaltschmidt C, Kaltschmidt B, Offenhäuser N, Böhm-Mattaei R, Baeuerle PA, Barde YA (1996a) Selective activation of NF- $\kappa$ B by nerve growth factor through the neurotrophin receptor $\mathrm{p} 75$. Nature 272:542-545.

Carter BD, Kaltschmidt C, Dechant G, Casademunt E, Chao MV, Barde YA (1996b) Mechanisms of signal transduction through the p75 neurotrophin receptor. Soc Neurosci Abstr 22:482.10.

Casaccia-Bonnefil P, Carter BD, Dobrowsky RT, Chao MV (1996) Death of oligodendrocytes mediated by the interaction of nerve growth factor with its receptor p75. Nature 282:716-719.

Chao MV, Hempstead BL (1995) p75 and Trk: a two receptor system. Trends Neurosci 18:321-326.

Clary DO, Weskamp G, Austin LR, Reichardt LF (1994) TrkA crosslinking mimics neuronal responses to nerve growth factor. Mol Biol Cell 5:549-563.

Coffey ET, Åkerman KEO, Courtney MJ (1995) Regulation of cerebellar granule cell development by BDNF and depolarization. Soc Neurosci Abstr 21:422.5.

Copani A, Bruno VMG, Barresi V, Battaglia G, Condorelli DF, Nicoletti F (1995) Activation of metabotropic glutamate receptors prevents neuronal apoptosis in culture. J Neurochem 64:101-108.

Cordon-Cardo C, Tapley P, Jing SQ, Nanduri V, O'Rourke E, Lamballe F, Kovary K, Klein R, Jones KR, Reichardt LF, Barbacid M (1991) The trk tyrosine protein kinase mediates the mitogenic properties of nerve growth factor and neurotrophin-3. Cell 66:173-183.

Cortazzo MH, Kassis ES, Sproul KA, Schor NF (1996) Nerve growth 
factor (NGF)-mediated protection of neural crest cells from antimitotic agent-induced apoptosis: the role of the low-affinity NGF receptor. J Neurosci 16:3895-3899.

Courtney MJ, Nicholls DG (1992) Interactions between phospholipase C-coupled and NMDA receptor in cultured cerebellar granule cells: protein kinase C-mediated inhibition of NMDA responses. J Neurochem 59:983-992.

Courtney MJ, Lambert JJ, Nicholls DG (1990) The interactions between plasma membrane depolarization and glutamate receptor activation in the regulation of cytoplasmic-free calcium in cultured cerebellar granule cells. J Neurosci 10:3873-3879.

Cuvillier O, Pirianov G, Kleuser B, Vanek PG, Coso OA, Gutkind JS, Spiegel S (1996) Suppression of ceramide-mediated programmed cell death by sphingosine-1-phosphate. Nature 381:800-803.

Dobrowsky RT, Werner MH, Castellino AM, Chao MV, Hannun YA (1994) Activation of the sphingomyelin cycle through the low-affinity neurotrophin receptor. Science 265:1596-1599.

Dobrowsky RT, Jenkins GM, Hannun YA (1995) Neurotrophins induce sphingomyelin hydrolysis. J Biol Chem 270:22135-22142.

Doherty P, Ashton SV, Moore SE, Walsh FS (1991) Morphoregulatory activities of NCAM and $N$-cadherin can be accounted for by G-proteindependent activation of $\mathrm{L}$ and $\mathrm{N}$-type neuronal $\mathrm{Ca}^{+}$channels. Cell 67:21-33.

Elliott LH, Wilkinson SE, Sedgwick AD, Hill CH, Lawton G, Davis PD, Nixon JS (1990) K252a is a potent and selective inhibitor of phosphorylase kinase. Biochem Biophys Res Commun 171:148-154.

Frade JM, Rodriguez-Tebar A, Barde YA (1996) Induction of cell death by endogenous nerve growth factor through its p75 receptor. Nature 383:166-168.

Gallo V, Kingsbury A, Balazs R, Jorgensen OS (1987) The role of depolarization in the survival and differentiation of cerebellar granule cells in culture. J Neurosci 7:2203-2213.

Gao WQ, Zheng JL, Karihaloo M (1995) Neurotrophin-4/5 (NT-4/5) and brain-derived neurotrophic factor (BDNF) act at later stages of cerebellar granule cell differentiation. J Neurosci 15:2656-2667.

Gilmore TD (1996) Regulation of Rel transcription complexes. In: Eukaryotic gene transcription (Goodbourne S, ed), pp 102-131. Oxford: IRL, Oxford UP

Glass DJ, Yancopoulos GD (1993) The neurotrophins and their receptors. Trends Cell Biol 3:262-267.

Grilli M, Pizzi M, Memo M, Spano P (1996) Neuroprotection by aspirin and sodium salicylate through blockade of NF- $\kappa \mathrm{B}$ activation. Science 274:1383-1385.

Guerrini L, Blasi F, Denis-Donini S (1995) Synaptic activation of NF- $\kappa$ B by glutamate in cerebellar granule neurons in vitro. Proc Natl Acad Sci USA 92:9077-9081.

Hallahan DE, Dunphy E, Virudachalam S, Sukhatme VP, Kufe DW, Weichselbaum RR (1995) c-Jun and Egr-1 participate in DNA synthesis and cell survival in response to ionizing radiation exposure. J Biol Chem 270:30303-30309.

Ham J, Babij C, Whitfield J, Pfarr CM, Lallemand D, Yaniv M, Rubin LL (1995) A c-Jun dominant negative mutant protects sympathetic neurons against programmed cell death. Neuron 14:927-939.

Harlow E, Lane D (1988) Antibodies. A laboratory manual. Cold Spring Harbor, NY: Cold Spring Harbor Laboratory.

Hashimoto Y, Nakayama T, Teramoto T, Kato H, Watanabe T, Kinoshita M, Tsukamoto K, Tokunaga K, Kurokawa K, Nakanishi S, Matsuda Y, Nomura Y (1991) Potent and preferential inhibition of $\mathrm{Ca}^{2+}$, calmodulin-dependent protein kinase II by K252a and its derivative, KT5926. Biochem Biophys Res Commun 181:423-429.

Heasley LE, Storey B, Fanger GR, Butterfield L, Zamarripa J, Blumberg $D$, Maue RA (1996) GTPase-deficient $G$ alpha 16 and $G$ alpha $q$ induce PC12 cell differentiation and persistent activation of c-Jun NH2 terminal kinases. Mol Cell Biol 16:648-656.

Hsu H, Shu HB, Pan MG, Goeddel DV (1996) TRADD-TRAF2 and TRADD-FADD interactions define two distinct TNF receptor 1 signal transduction pathways. Cell 84:299-308.

Huang T-S, Lee S-C, Lin J-K (1991) Suppression of c-Jun/AP-1 activation by an inhibitor of tumor promotion in mouse fibroblast cells. Proc Natl Acad Sci USA 88:5292-5296.

Huber LJ, Chao MV (1995) Mesenchymal and neuronal cell expression of the p75 neurotrophin receptor gene occur by different mechanisms. Dev Biol 167:227-238.

Ito A, Horigome K (1995) Ceramide prevents neuronal programmed cell death induced by nerve growth factor deprivation. J Neurochem 65:463-466.

Johnson NL, Gardner AM, Diener KM, Lange-Carter CA, Gleavy J, Jarpe MB, Minden A, Karin M, Zon LI, Johnson GL (1996) Signal transduction pathways regulated by mitogen-activated/extracellular response kinase kinase kinase induce cell death. J Biol Chem 271:3229-3237.

Juurlink BH, Hertz L (1993) Ischemia-induced death of astrocytes and neurons in primary culture: pitfalls in quantifying neuronal cell death. Dev Brain Res 71:239-246.

Kao JPY, Harootunian AT, Tsien RY (1989) Photochemically generated cytosolic calcium pulses and their detection by Fluo-3. J Biol Chem 264:8179-8184

Karin M, Hunter T (1995) Transcriptional control by protein phosphorylation: signal transmission from the cell surface to the nucleus. Curr Biol 5:747-757.

Kase H, Iwahashi K, Nakanishi S, Matsuda Y, Yamada K, Takahashi M, Murakata C, Sato A, Kaneko M (1987) K-252 compounds, novel and potent inhibitors of protein kinase $\mathrm{C}$ and cyclic nucleotide-dependent protein kinases. Biochem Biophys Res Commun 142:436-440.

Kingsbury AE, Gallo V, Woodhams PL, Balazs R (1985) Survival, morphology, and adhesion properties of cerebral interneurones cultured in chemically defined and serum-supplemented medium. Dev Brain Res $17: 17-25$.

Kolch W, Heidecker G, Kochs G, Hummel R, Vahidi H, Mischak H, Finkenzeller G, Marmé D, Rapp UR (1993) Protein kinase C $\alpha$ activates Raf-1 by direct phosphorylation. Nature 364:249-252.

Krueger BK, Burne JF, Raff MC (1995) Evidence for large-scale astrocyte death in the developing cerebellum. J Neurosci 15:3366-3374.

Kyriakis JM, Banerjee P, Nikolakaki E, Dai T, Rubie EA, Ahmad MF, Avruch J, Woodgett JR (1994) The stress-activated protein kinase subfamily of c-Jun kinases. Nature 369:156-160.

Kyriakis JM, Woodgett JR, Avruch J (1995) The stress-activated protein kinases. A novel ERK subfamily responsive to cellular stress and inflammatory cytokines. Ann NY Acad Sci 766:303-319.

Landis DMD, Sidman RL (1978) Electron microscopic analysis of postnatal histogenesis in the cerebellar cortex of staggerer mutant mice. J Comp Neurol 179:831-864.

Lindholm D, Dechant G, Heisenberg CP, Thoenen H (1993) Brainderived neurotrophic factor is a survival factor for cultured cerebellar granule neurons and protects them against glutamate-induced neurotoxicity. Eur J Neurosci 5:1455-1464.

Lindqvist C, Holmberg C, Oetken C, Courtney M, Ståhls A, Åkerman KEO (1995) Rapid Ca mobilization in single LGL cells upon interaction with K562 target cells-role of the CD18 and CD16 molecules. Cell Immunol 165:71-76.

Liu ZG, Hsu H, Goeddel DV, Karin M (1996) Dissection of TNF receptor 1 effector functions: JNK activation is not linked to apoptosis, while NF- $\kappa$ B activation prevents cell death. Cell 87:565-575.

Mahadeo D, Kaplan L, Chao MV, Hempstead BL (1994) High-affinity nerve growth factor binding displays a faster rate of association than p140 ${ }^{\text {trk }}$ binding. Implications for multi-subunit polypeptide receptors. J Biol Chem 269:6884-6891.

Masuelli L, Cutler ML (1996) Increased expression of the ras suppressor rsu- 1 enhances erk- 2 activation and inhibits jun kinase activation. Mol Cell Biol 16:5466-5476.

Menon SD, Qin S, Guy GR, Tan YH (1993) Differential induction of nuclear NF- $\kappa$ B by protein phosphatase inhibitors in primary and transformed human cells. Requirement for both oxidation and phosphorylation in nuclear translocation. J Biol Chem 268:26805-26812.

Minden A, Lin A, McMahon M, Lange-Carter C, Dérijard B, Davis RJ, Johnson GL, Karin M (1994) Differential activation of ERK and JNK mitogen-activated protein kinases by Raf-1 and MEKK. Science 266:1719-1723.

Musti AM, Treier M, Bohmann D (1997) Reduced ubiquitin-dependent degradation of c-Jun after phosphorylation by MAP kinases. Science 275:400-402.

Natoli G, Costanzo A, Ianni A, Templeton DJ, Woodgett JR, Balsano C, Levrero M (1997) Activation of SAPK/JNK by TNF receptor 1 through a noncytotoxic TRAF2-dependent pathway. Science 275: 200-203.

Nishina H, Fischer KD, Radvanyi L, Shahinian A, Hakem R, Rubie EA, Bernstein A, Mak TW, Woodgett JR, Penninger JM (1997) Stresssignalling kinase Sek1 protects thymocytes from apoptosis mediated by CD95 and CD3. Nature 385:350-353. 
Obeid LM, Linardic CM, Karolak LA, Hannun YA (1993) Programmed cell death induced by ceramide. Science 259:1769-1771.

Ohmichi M, Pang L, Decker SJ, Saltiel AR (1992) Nerve growth factor stimulates the activities of the raf-1 and the mitogen-activated protein kinases via the trk protooncogene. J Biol Chem 267:14604-14610.

Okada T, Sakuma L, Fukui Y, Hazeki O, Ui M (1994) Blockage of chemotactic peptide-induced stimulation of neutrophils by wortmannin as a result of selective inhibition of phosphatidylinositol-3 kinase. J Biol Chem 269:3563-3567.

Pulverer BJ, Hughes K, Franklin CF, Kraft CS, Leevers SJ, Woodgett JR (1993) Co-purification of mitogen-activated protein kinases with phorbol ester-induced c-Jun kinase activity in U937 leukemic cells. Nature 353:670-674.

Rabizadeh S, Oh J, Zhong LT, Yang J, Bitler CM, Butcher LL, Bredesen DE (1993) Induction of apoptosis by the low-affinity NGF receptor. Science 261:345-348.

Resink A, Hack N, Boer GJ, Balazs R (1994) Growth conditions differentially modulate the vulnerability of developing cerebellar granule cells to excitatory amino acids. Brain Res 655:222-232.

Sakata N, Patel HR, Terada N, Aruffo A, Johnson GL, Gelfand EW (1995) Selective activation of c-Jun kinase mitogen-activated protein kinase by CD40 on human B cells. J Biol Chem 270:30823-30828.

Sassone-Corsi P, Sisson JC, Verma IM (1988) Transcriptional autoregulation of the proto-oncogene fos. Nature 334:314-319.

Segal RA, Takahashi H, McKay RD (1992) Changes in neurotrophin responsiveness during the development of cerebellar granule neurons. Neuron 9:1041-1052.

Segal RA, Pomeroy SL, Stiles CD (1995) Axonal growth and fasciculation linked to differential expression of BDNF and NT-3 in developing cerebellar granule cells. J Neurosci 15:4970-4981.

Singh S, Aggarwal BB (1995) Activation of transcription factor NF- $\kappa$ B is suppressed by curcumin (diferuloymethane). J Biol Chem 270:24995-25000.

Soppet D, Escandon E, Maragos J, Middlemas DS, Reid SW, Blair J, Burton LE, Stanton BR, Kaplan DR, Hunter T, Nikilics K, Parada LF (1991) The neurotrophic factors brain-derived neurotrophic factor and neurotrophin-3 are ligands for the trkB tyrosine kinase receptor. Cell 65:895-903.

Su B, Jacinto E, Hibi M, Kallunki T, Karin M, Ben-Neriah Y (1994) JNK is involved in signal integration during costimulation of $\mathrm{T}$ lymphocytes. Cell 77:727-736.

Thangnipon W, Kingsbury A, Webb M, Balazs R (1983) Observations on rat cerebellar granule cells in vitro: influence of substratum, potassium concentration, and relationship between neurones and astrocytes. Eur J Pharmacol 140:275-283.

Tapley P, Lamballe F, Barbacid M (1992) K252a is a selective inhibitor of the tyrosine protein kinase activity of the trk family of oncogenes and neurotrophin receptors. Oncogene 7:371-381.
Thompson MA, Ginty DD, Bonni A, Greenberg ME (1995) L-type voltagesensitive $\mathrm{Ca}^{2+}$ channel activation regulates c-fos transcription at multiple levels. J Biol Chem 270:4224-4235.

Toullec D, Pianetti P, Coste H, Bellevergue P, Grand-Perret T, Ajakane M, Baudet V, Biossin E, Boursier E, Loriolle F, Duhame L, Charon D, Kirilovsky J (1991) The bisindolylmaleimide GF $109203 \mathrm{X}$ is a potent and selective inhibitor of protein kinase C. J Biol Chem 266:15771-15781.

Van Antwerp DJ, Martin SJ, Kafri T, Green DR, Verma IM (1996) Suppression of TNF- $\alpha$-induced apoptosis by NF- $\kappa$ B. Science 274:787-789.

Verheij M, Bose R, Lin XH, Yao B, Jarvis WD, Grant S, Birrer MJ, Szabo E, Zon LI, Kyriakis JM, Haimovitz-Friedman A, Fuks Z, Kolesnick RN (1996) Requirement for ceramide-initiated SAPK/JNK signalling in stress-induced apoptosis. Nature 380:75-79.

Vetter ML, Martin-Zanca D, Parada LF, Bishop JM, Kaplan DR (1991) Nerve growth factor rapidly stimulates tyrosine phosphorylation of phospholipase $\mathrm{C}$ gamma 1 by a kinase activity associated with the product of the trk protooncogene. Proc Natl Acad Sci USA 88:5650-5654.

Wang C-Y, Mayo MW, Baldwin Jr AS (1996) TNF- $\alpha$ and cancer therapyinduced apoptosis: potentiation by inhibition of NF- $\kappa$ B. Science 274:784-787.

Weber A, Schachner M (1984) Maintenance of immunocytologically identified Purkinje cells from mouse cerebellum in monolayer culture. Brain Res 311:119-130.

Westwick JK, Bielawska AE, Dbaibo G, Hannun YA, Brenner DA (1995) Ceramide activates the stress-activated protein kinases. J Biol Chem 270:22689-22692.

Wood KA, Dipasquale B, Youle RJ (1993) In situ labeling of granule cells for apoptosis-associated DNA fragmentation reveals different mechanisms of cell loss in developing cerebellum. Neuron 11:621-632.

Xia Z, Dickens M, Raingeaud J, Davis RJ, Greenberg ME (1995) Opposing effects of ERK and JNK-p38 MAP kinases on apoptosis. Science 270:1326-1331.

Yanaga F, Watson SP (1992) Tumor necrosis factor alpha stimulates sphingomyelinase through the $55 \mathrm{kDa}$ receptor in HL-60 cells. FEBS Lett 314:297-300.

Yang Z, Costanzo M, Golde DW, Kolesnick RN (1993) Tumor necrosis factor activation of the sphingomyelin pathway signals nuclear factor $\kappa \mathrm{B}$ translocation in intact HL-60 cells. J Biol Chem 268:20520-20523.

Yao R, Cooper GM (1995) Requirement for phosphatidylinositol-3 kinase in the prevention of apoptosis by nerve growth factor. Science 267:2003-2006.

Zirrgiebel U, Ohga Y, Carter B, Berninger B, Inagaki N, Thoenen H, Lindholm D (1995) Characterisation of TrkB receptor-mediated signaling pathways in rat cerebellar granule neurons: involvement of protein kinase C in neuronal survival. J Neurochem 65:2241-2250. 